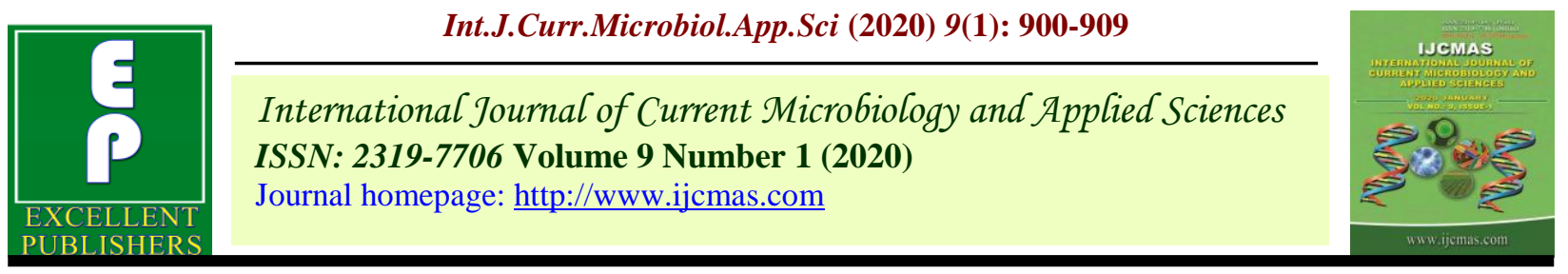

Original Research Article

https://doi.org/10.20546/ijcmas.2020.901.100

\title{
Purification of Industrially Important Proteases from Pseudomonas Strain and Its Kinetic Studies
}

\author{
Mohinder Kaur ${ }^{1}$, Sheetal $\operatorname{Rana}^{2^{* *}}$ and Kumari Manorma ${ }^{3}$ \\ ${ }^{1}$ Department of Basic Science (Microbiology), Dr. Yashwant Singh Parmar University of \\ Horticulture and Forestry, Nauni, Solan-173230 (HP), India \\ ${ }^{2}$ Department of organic agriculture and Natural Farming, \\ CSKHPKV, Palampur-176061 India \\ ${ }^{3}$ Department of Basic Science (Microbiology), Dr. Yashwant Singh Parmar University of \\ Horticulture and Forestry, Nauni, Solan-173230 (HP), India \\ *Corresponding author
}

\begin{tabular}{|l|}
\hline Ke y w o r d s \\
Pseudomonas \\
Antimicrobial, \\
Protease, \\
Purification, \\
Antifungal activity \\
\hline Article Info \\
\hline $\begin{array}{l}\text { Accepted: } \\
\text { 15 December } 2019 \\
\text { Available Online: } \\
\text { 20 January } 2020\end{array}$ \\
\hline
\end{tabular}

Keywords

Pseudomonas

Antimicrobial,

Protease,

Purification,

Antifungal activity

Article Info

Accepted:

Available Online:

\section{A B S T R A C T}

The aim of study was development of industrially and agriculturally important bacterial strains which produces antimicrobial protease. It is a kind of study that tends to contribute the potential Pseudomonas strains that may be helpful as plant growth promoting, biocontrol agent and may be used for the production of antimicrobial protease at industrial level. In the present study we have tried to isolate the fluorescent Pseudomonas sp. from three medicinal plants i.e., Achyranthus aspera, Elaegnus umbellate and Heracleum candicans. Three strains were isolated i.e., A4, H5 and E6, which were showed the high production of antibacterial, antifungal and proteolytic activity. The enzyme protease was purified from the strain $\mathrm{H} 5$ by using Sephadex G-75 column chromatography. Kinetic study of the purified protease was done by checking the effect of $\mathrm{pH}$ and temperature, substrate concentration, enzyme concentration and reaction time. Purified proteases can be exploited for industrial use as it is in high demands in different industries.

\section{Introduction}

Protease is an enzyme that helps break down protein. They are found in all organisms and are important in many internal metabolic functions, from digestion to blood clotting. Proteases execute a large variety of functions and have important biotechnological applications. Proteases represent one of the three largest groups of industrial enzymes and 
find application in detergents, leather industry, food industry, pharmaceutical industry and bioremediation processes (Anwar and Saleemuddin, 1998; Gupta et al., 2002). Probably the largest application of proteases is in laundry detergents, where they help removing protein based stains from clothing (Banerjee et al., 1999).

Proteases have been used in food for centuries. A type of protease called rennet, obtained from the stomachs of unweaned calves, has traditionally been used in the production of cheese. Proteases also play a part in the production of soy sauce, sausages, luncheon meat and flour.

They also have a role to play in medical, proteases are used to treat blood clots, clean wounds and to enhance the effectiveness of some antibiotics. One type of protease obtained from pineapple stems is used as an anti-inflammatory, and other proteindegrading protease enzymes are used to treat severe sepsis.

Microorganisms are the most important sources for enzyme production. Selection of the right organism plays a key role in high yield of desirable enzymes. For production of enzymes for industrial use, isolation and characterization of new promising strains using cheap carbon and nitrogen source is a continuous process.

\section{Materials and Methods}

\section{Isolation and identification of fluorescent Pseudomonas sp.}

Soil samples were collected from the rhizosphere soil of three medicinal plants i.e., Achyranthus aspera, Elaegnus umbellate and Heracleum candicans from the medicinal plant field of Dr Y.S. Parmar University of Horticulture and Forestry, Nauni Solan. Three fluorescent Pseudomonas sp. $\left(\mathrm{A}_{4}, \mathrm{E}_{6}\right.$ and $\left.\mathrm{H}_{5}\right)$ were isolated on King's media A by serial dilution method. Strains were identified as Pseudomonas sp. on the basis of biochemical testings and were confirmed from Department of Microbiology, Indira Gandhi medical college, Shimla.

\section{Screening of isolates for the production of antimicrobial activity}

\section{Antagonistic activities}

Standard indicator test bacteria viz., Bacillus subtilis, Staphylococcus, E. coli, Klebsiella sp., Pseudomonas sp., shigella sp., Salmonella typhi, $S$. paratyphi and Xanthomonas sp. were used for testing antibacterial activity and were maintained on nutrient agar at $4^{\circ} \mathrm{C}$ and subcultured periodically at $37^{\circ} \mathrm{C}$ on the same media.

A number of test fungi were also tested against the Pseudomonas sp. viz., Alternaria sp., Aspergillus sp., Fusarium sp., Penicillium sp., Phytophthora sp., Pythium sp., Trichoderma sp., and Trichothecium sp.

Antibacterial and antifungal activity was checked by standard well plate assay method (Fleming et al., 1975). 100 $\mu 1$ of culture free supernatant were used and plates were incubated at $37^{\circ} \mathrm{C}$ and were observed for the formation of inhibition zone around the well.

\section{Proteolytic activity}

Three Pseudomonas strains $\mathrm{A}_{4}, \mathrm{E}_{6}$ and $\mathrm{H}_{5}$ were screened out for the proteolytic activity by well plate assay method. For this skim milk agar plates were made. $100 \mu \mathrm{l}$ of $72 \mathrm{~h}$ old cell free culture supernatant of each strain was added to each well. Plates were incubated at $37^{\circ} \mathrm{C}$ for $24-48 \mathrm{~h}$ and were observed for the formation of clear zone around the well. 


\section{Partial purification of antimicrobial proteolytic activity}

Antimicrobial proteolytic activities were purified according to the method of Morihara et al.,(1965) with slight modifications. Protein was precipitated by ammonium sulphate precipitation and saturation was obtained at $80 \%$ and also by acetone precipitation $(65 \%)$. The precipitated sample of protein was partially purified by column chromatography on Sephadex G-75. The columns were packed with the head pressure of $1.5 \times 30 \mathrm{~cm}$ buffer column and washed with about $250 \mathrm{ml}$ of tris buffer. $1 \mathrm{ml}$ of crude preparation were applied at the top of the column and head pressure was maintained to achieve a flow rate of $24 \mathrm{ml} / \mathrm{h}$. Fraction of three $\mathrm{ml}$ were collected and each fraction was read at 280nm.(spectrophotometer Shimadzu UV1601).Antimicrobial proteolytic activities were assayed by respective well plate assay method from each fraction. Fractions showing proteolytic activities were pooled and concentrated against powdered sucrose in dialyzing bag. Molecular weight was also calculated by calibrating the column with pepsin (36000), alpha- chymotrypsin $(25,300)$, soyabean trypsin inhibitor $(21,500)$, pancreatic ribonuclease (13680) and ovalbumin (43000). The ratio of elution volume to void volume was plotted against the molecular weight of known protein.

\section{Protein estimation}

Crude and purified pooled fractions were assayed for protein $(\mathrm{mg} / \mathrm{ml})$ by Lowry method (Lowry et al., 1951) and Biuret method (Gornall et al., 1949 and Sticklend, 1951), employing respective standard curve calibrated with bovine serum albumin (BSA).

\section{PAGE}

Disc electrophoresis of the partially purified and purified antimicrobial proteolytic activities was carried out to see the homogeneity of the preparations by the method of Cooksey (1971). The one unstained gels of the samples were tested for proteolytic activity by placing gel on the skim milk agar plate. Plates incubated at $37^{\circ} \mathrm{C}$ for 24 to $72 \mathrm{~h}$ subsequently at $4^{0} \mathrm{C}$ till a measurable clear zone appeared in the plate.

\section{Enzyme kinetic}

Kinetics of antimicrobial protease obtained and purified from Pseudomonas strain was studied using colorimetric method of Sandhia and Prema (1998) and Tsuchida et al., (1986) with modifications, effect of $\mathrm{pH}$, substrate concentration, enzyme concentration, reaction time and incubation temperature were studied.

\section{Results and Discussion}

The ability of soil microorganisms to synthesize various secondary idiolites may affect the growth and health of plant, soil properties and improve soil fertility (Vancura and Jandera, 1986). The diversity of the microorganisms selected from enrichment environment may be diversified that they may be able to produce useful bioactive substances and biocatalysts due to environmental stress conditions (Cheetham, 1987 and Steele and Stowers, 1991). So the Pseudomonas strains $\mathrm{A}_{4}, \mathrm{H}_{5}$ and $\mathrm{E}_{6}$ were used in present study and were screened out for the antibacterial activity, antifungal activity and proteolytic activity. The three isolates of Pseudomonas strains $\mathrm{A}_{4}, \mathrm{E}_{6}$ and $\mathrm{H}_{5}$ were screened out for antibacterial activity against nine indicator bacteria. The maximum zone of inhibition was found against $B$. subtilis (22mm dia.) by $\mathrm{A}_{4}$. $\mathrm{A}_{4}$ was also found to show antagonistic activity against Xanthomonas sp. (14mm), Shigella sp. (12mm), Klebsiella sp. (10mm) and $S$. typhi (W). Pseudomonas sp. E6 was found to show maximum inhibition against $B$. subtilis $(24 \mathrm{~mm})$ followed by Xanthomonas (15mm), Pseudomonas sp. (14mm), 
Klebsiella sp. (10mm). similarly maximum inhibition was shown by $\mathrm{H} 5$ against $B$. subtilis $(26 \mathrm{~mm})$ followed by Xanthomonas $\mathrm{sp}$ (18mm), Pseudomonas sp.(18mm), Shigella sp. (14mm) (Table 1.). The production of antimicrobial activities was maximum at $37^{\circ} \mathrm{C}, \mathrm{pH} 7.0$ and $72 \mathrm{~h}$ of incubation period under shake conditions (90rpm). Pseudomonas strain H5 was found best for the production of antimicrobial activities. Best production of all the three antimicrobial activities were found to be in nutrient broth yeast extract, King's medium A, King's medium B, respectively for Pseudomonas strains A4, E6 and H5.

The results showed that the maximum zone of inhibition was found against Phytophthora sp. $(24 \mathrm{~mm}, 22 \mathrm{~mm}$ and $20 \mathrm{~mm})$ by $\mathrm{H}_{5}, \mathrm{~A}_{4}$ and $\mathrm{E}_{6}$ respectively. $\mathrm{A}_{4}$ also showed activity against Fusarium sp. (12mm), Penicillium sp. (10mm), Pythium sp. (10mm) and Alternaria sp. $(8 \mathrm{~mm})$. While $\mathrm{E}_{6}$ was found to show antagonistic activity against Trichothecium sp. $(12 \mathrm{~mm})$ and Pythium sp. $(9 \mathrm{~mm})$. Pseudomonas strain $\mathrm{H}_{5}$ showed inhibitory activity against Trichoderma sp. (18mm) and Aspergillus sp. (12mm) (Table 2).

Three strains of Pseudomonas sp. were screened out for the proteolytic activity on skim milk agar plate. Results yield maximum zone of proteolytic activity $(24 \mathrm{~mm}, 22 \mathrm{~mm}$ and $18 \mathrm{~mm}$ ) by $\mathrm{H}_{5}, \mathrm{E}_{6}$ and $\mathrm{A}_{4}$ respectively (Table 3).

\section{Purification of antimicrobial protease activity from strain $\mathrm{H5}$}

Antimicrobial protease were concentrate and purified by ammonium sulphate (80\%), acetone $(65 \%)$ and Sephadex G 75 column chromatography and achieved 22.2, 23.0 and 41.5 folds increase in activities in $\mathrm{H} 5$ supernatant. The results of purification of extracellular antimicrobial protease activity showed that most of the activities from supernatant could be salted out with ammonium sulphate $(80 \%)$ saturation. It was also reported by Morihara et al., (1965). The column chromatographic pattern of these preparations on Sephadex G-75 showed that the activities were present in fraction 6-14 and 21-25 in case of $\mathrm{H}_{5}$ (Fig 1). Bacterial proteolytic enzymes especially elastase has been purified from culture filtrates of Pseudomonas in which ammonium sulphate precipitation was followed by column chromatography (Wretlind and Wadstorm, 1977 and Morihara and Tsuzuki, 1977)

Polyacrylamide gel electrophoresis of the pool of the fraction showing antimicrobial proteolytic activity revealed one major protein component. Strain $\mathrm{H}_{5}$ gave a number of bands in stained gel. The parallel unstained gel was kept on skim milk agar plate just after the electrophoresis and was incubated at $37^{\circ} \mathrm{C}$ for 24-72h. It was observed to show proteolytic activity. A clear zone was produced by Sephadex filter purified preparation of stained gel. The molecular weight of the antimicrobial protease of Pseudomonas strain H5 have been found to approximately 32000 on column chromatography. It can be assorted that this is an extracellular enzyme and might have similar sequence area in the genes synthesizing antimicrobial protease in different bacterial species as has been anticipated by Ramley (1979) for secretory proteins.

\section{Enzyme kinetics of antimicrobial protease activity}

Living cells are successful in carrying out thermodynamically favourable reactions under standard conditions of concentration, temperature, $\mathrm{pH}$, pressure, and environment and are equally successful in integrating and regulating this reaction. 
Table.1 Screening of antibacterial activity of Pseudomonas strains A4, E6 and H5 by well plate assay method at $37^{0} \mathrm{C}$ for $24 \mathrm{~h}$

\begin{tabular}{|l|l|l|l|l|l|l|l|l|l|}
\hline \multirow{2}{*}{$\begin{array}{l}\text { Pseudomonas } \\
\text { strains }\end{array}$} & \multicolumn{8}{|c|}{ Antibacterial activities (mm dia) } \\
\hline & $\begin{array}{l}\text { B. } \\
\text { subtilis }\end{array}$ & Staphylococcus & $\begin{array}{l}\text { E. } \\
\text { colicator test bacteria }\end{array}$ & $\begin{array}{l}\text { Klebsiella } \\
\text { spp. }\end{array}$ & $\begin{array}{l}\text { Pseudomonas } \\
\text { spp. }\end{array}$ & $\begin{array}{l}\text { Shigella } \\
\text { spp. }\end{array}$ & $\begin{array}{l}\text { S. } \\
\text { typhi }\end{array}$ & $\begin{array}{l}\text { S. } \\
\text { paratyphi }\end{array}$ & $\begin{array}{l}\text { Xanthomonas } \\
\text { spp. }\end{array}$ \\
\hline A4 & 22 & - & - & 10 & - & 12 & W & W & 14 \\
\hline E6 & 24 & - & W & 10 & 14 & - & - & W & 15 \\
\hline H5 & 26 & - & W & W & 18 & 14 & - & - & 18 \\
\hline
\end{tabular}

- Indicates no activity, $\quad \mathrm{w}$ indicates weak activity

Table.2 Screening of antifungal activity of Pseudomonas strains A4, E6 and H5 by well plate assay method at $37^{\circ} \mathrm{C}$ for $24 \mathrm{~h}$

\begin{tabular}{|l|l|l|l|l|l|l|l|l|}
\hline \multirow{2}{*}{$\begin{array}{l}\text { Pseudomonas } \\
\text { strains }\end{array}$} & \multicolumn{9}{|c|}{ Antifungal activities (mm dia) } \\
\hline & \multicolumn{9}{|c|}{ Indicator test fungi } \\
\hline & Alternaria & Aspergillus & Fusarium & Penicillium & Phytophthora & Pythium & Trichoderma & Trichothecium \\
\hline A4 & 8 & - & 12 & 10 & 22 & 10 & - & - \\
\hline E6 & - & - & - & - & 20 & 9 & - & 12 \\
\hline H5 & - & 12 & - & w & 24 & - & -18 & - \\
\hline
\end{tabular}

Table.3 Screening of proteolytic activity of Pseudomonas strains A4, E6 and H5 by well plate assay method at 370C for 24h

\begin{tabular}{|c|c|}
\hline Pseudomonas strains & Proteolytic activity (mm dia) \\
\hline A4 & 18 \\
\hline E6 & 22 \\
\hline H5 & 24 \\
\hline
\end{tabular}




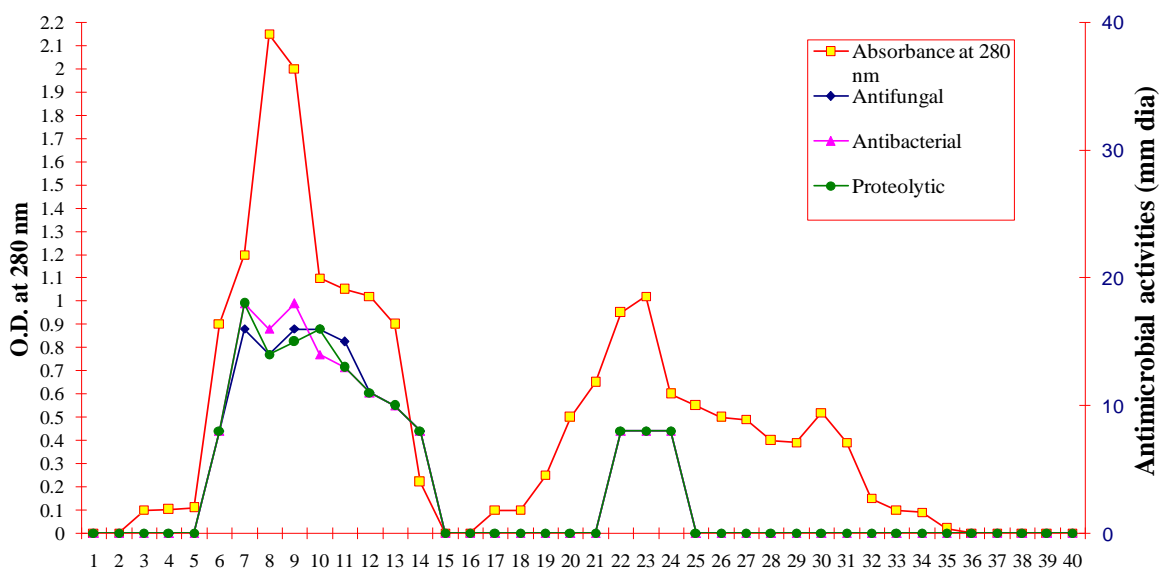

Fraction number

Fig. 1. Pseudomonas strain H5

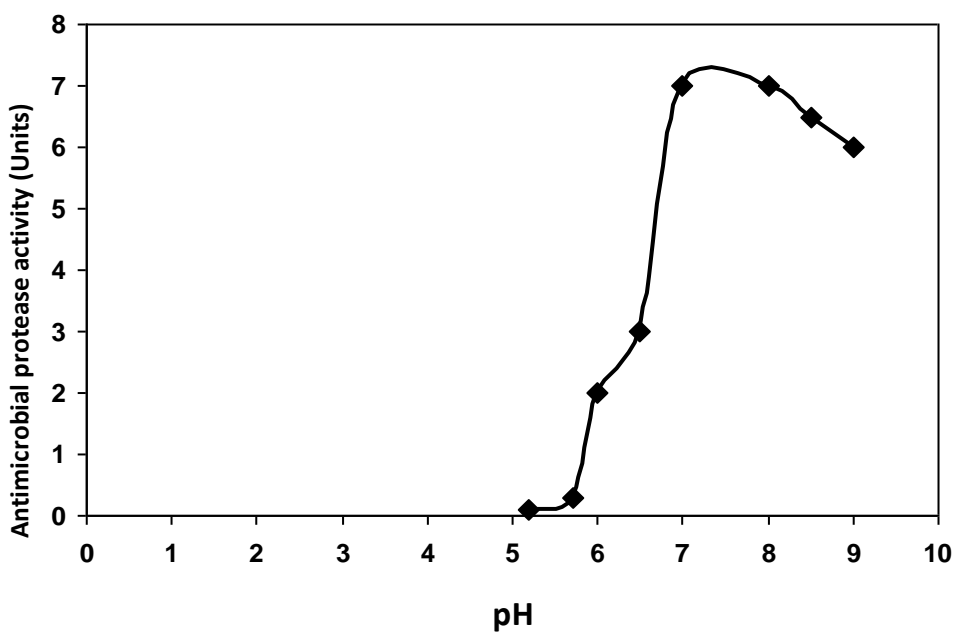

Fig. 2. Effect of $\mathrm{pH}$ on the activity of antimicrobial protease from Pseudomonas strain $\mathrm{H}_{5}$ in Tris-maleate buffer $(0.05 \mathrm{M})$ at $37^{\circ} \mathrm{C}$ for 10 minutes. The reaction mixture consisted of $10 \mathrm{mg}$ of casein and $0.5 \mathrm{mg}$ of enzyme protein from Pseudomonas strain $\mathrm{H}_{5}$ 


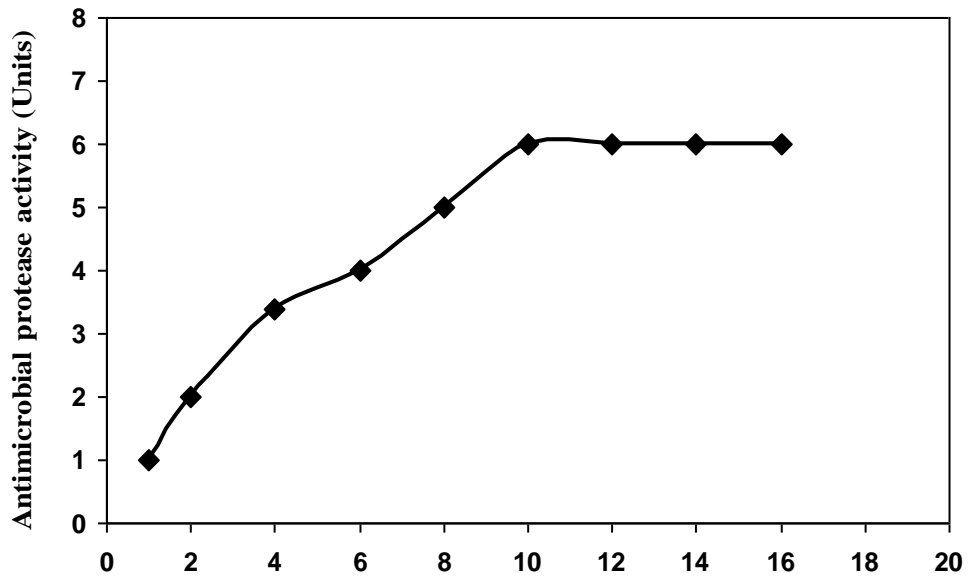

Substrate concentration (mg casein)

Fig. 3. Effect of substrate concentration on the activity of antimicrobial protease from Pseudomonas strain $\mathrm{H}_{5}$ in Tris $\mathrm{HCl}$ buffer $(0.05 \mathrm{M}, \mathrm{pH}$ 7.0) at $37^{\circ} \mathrm{C}$ for 10 minutes. The reaction mixture consisted of $0.5 \mathrm{mg}$ of enzyme protein from from Pseudomonas strain $\mathrm{H}_{5}$ Tris $\mathrm{HCl}$ buffer

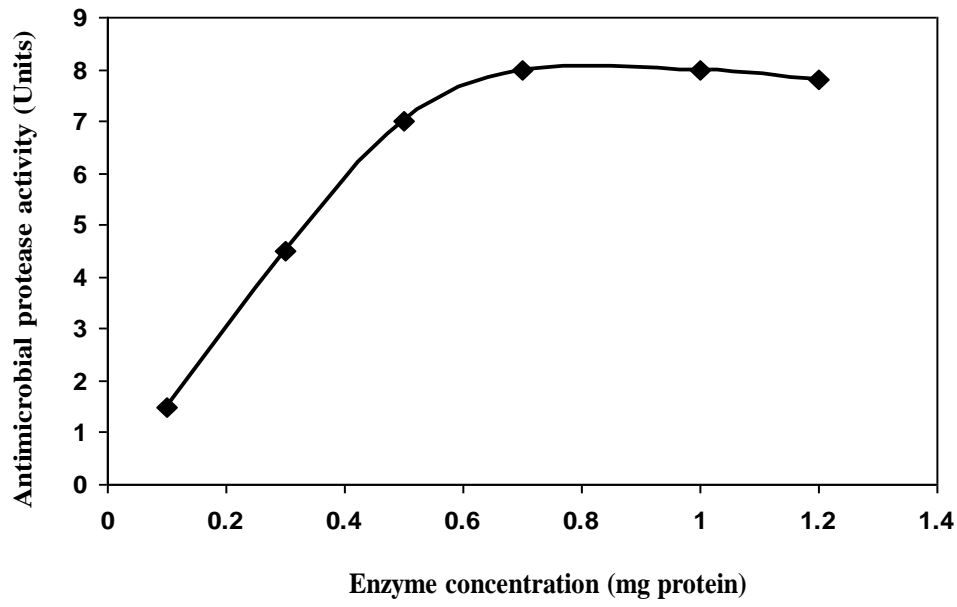

Fig. 4. Effect of enzyme concentration (mg protein) on the activity of antimicrobial protease from Pseudomonas strain $\mathrm{H}_{5}$ in Tris $\mathrm{HCl}$ buffer $(0.05 \mathrm{M}, \mathrm{pH} 7.0)$ at $37^{\circ} \mathrm{C}$ for 10 minutes. The reaction mixture consisted of $10 \mathrm{mg}$ of casein Tris $\mathrm{HCl}$ buffer 


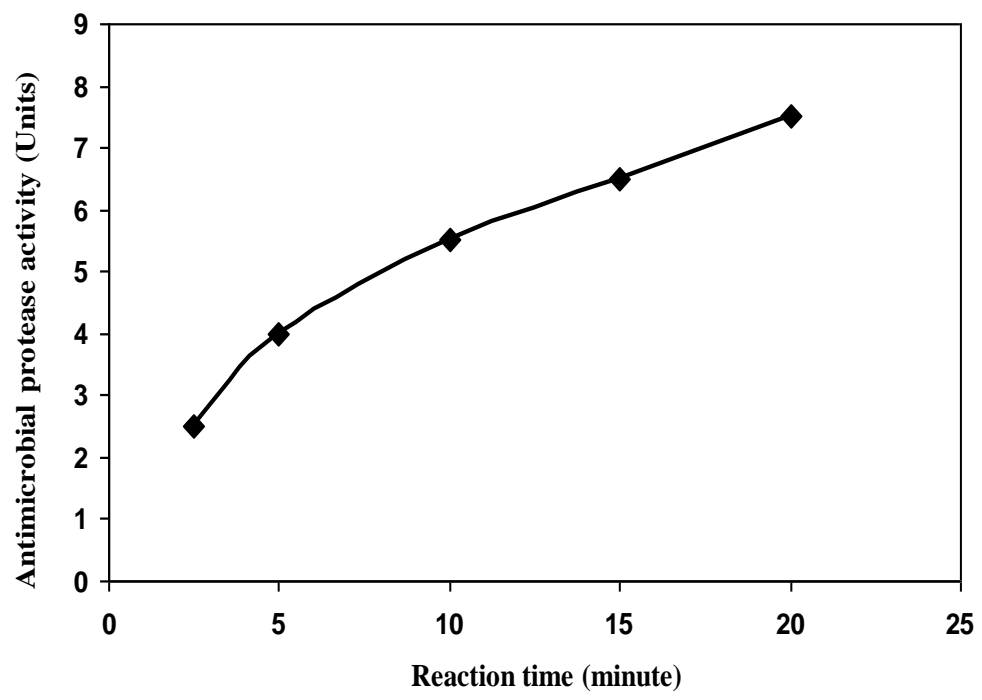

Fig. 5. Effect of reaction time on the activity of antimicrobial protease from Pseudomonas strain $\mathrm{H}_{5}$ in Tris $\mathrm{HCl}$ buffer $(0.05 \mathrm{M}, \mathrm{pH} \mathrm{7.0)}$ at $37^{\circ} \mathrm{C}$. The reaction mixture consisted of $10 \mathrm{mg}$ of casein and $0.5 \mathrm{mg}$ of enzyme protein from Pseudomonas strain $\mathrm{H}_{5}$ Tris $\mathrm{HCl}$ buffer

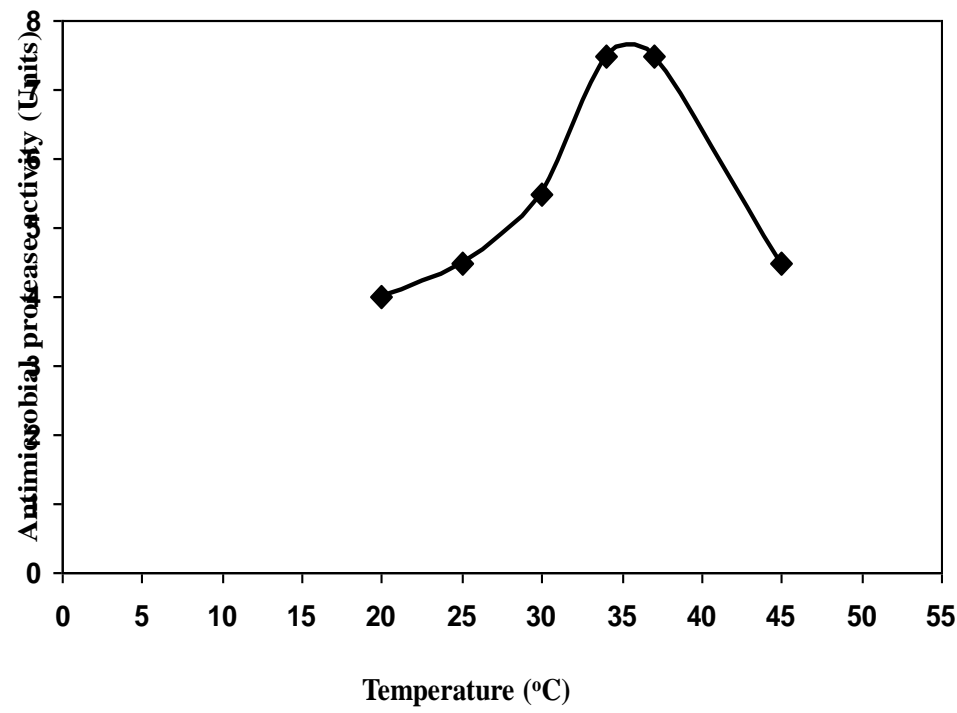

Fig. 6. Effect of temperature of incubation on the activity of antimicrobial protease from Pseudomonas strain $\mathrm{H}_{5}$ in Tris $\mathrm{HCl}$ buffer $(0.05 \mathrm{M}, \mathrm{pH} 7.0)$ at different temperature for 10 minute. The reaction mixture consisted of $0.5 \mathrm{mg}$ of enzyme protein from Pseudomonas strain $\mathrm{H}_{5}$ and $10 \mathrm{mg}$ Tris $\mathrm{HCl}$ buffer 
The key to press phenomenon is provided by the fact that virtually all intracellular processes are mediated by enzymes are protein that catalyse and accelerate the biochemical reaction. The most important factor affecting enzyme catalysed reaction study include $\mathrm{pH}$, temperature, substrate concentration, enzyme concentration and reaction time in the reaction mixture. The optimum $\mathrm{pH}$ for the activity of antimicrobial protease from Pseudomonas strain $\mathrm{H}_{5}$ was determined by using tris maleate buffer $(0.05 \mathrm{M})$ ranging from $\mathrm{pH} 5.2$ to 9.0 .The results showed that optimum $\mathrm{pH}$ for the antimicrobial protease activity from Pseudomonas strain $\mathrm{H}_{5}$ was 7.0-7.5(Fig 2). In literature the $\mathrm{pH}$ optima of proteases has been reported to vary, though from a single source in the presence of type of buffer used in the assay system (Morihara et al.,1965)

Effect of casein (1, 2,4,6,8,10,12,14 and $16 \mathrm{mg}$ ) per reaction mixture on the antimicrobial proteolytic activity was studied under standard experimental conditions at $37^{\circ} \mathrm{C}$ for $10 \mathrm{~min}(0.05 \mathrm{M}$ Tris-HCl buffer, $\mathrm{pH}$ 7.0) from the substrate curve. The results showed a constant increase in enzyme activity with increase in substrate concentration up to 10mg (Fig 3). Above this concentration the curve formed a plateau without any significant increase in enzyme activity.

Effect of enzyme concentration studies showed that there is a constant increase in enzyme activity with increase in enzyme protein up to $0.5 \mathrm{mg}$ (Fig. 4). Above this concentration the curve formed a plateau without any significant increase in enzyme activity.

The degradation of substrate was observed to have a linear relationship with the time of incubation of the reaction mixture. Maximum solubilization of casein was observed in 10 minutes (Fig. 5). Mandl and Cohen (1960) and Morihara(1964) have studied enzyme activity from Flavobacterium and Pseudomonas aeruginosa respectively for $3 \mathrm{~h}$ of reaction time. Sachar et al.,(1955) used $20 \mathrm{~min}$ as the reaction time in studying the elastase activity of pancreatic elastase.

The reaction mixture with $10 \mathrm{mg}$ casein, $0.5 \mathrm{mg}$ of enzyme protein from Pseudomonas strain was incubated at different temperature $\left(20,25,30,35,37\right.$ and $\left.45^{\circ} \mathrm{C}\right)$ for $10 \mathrm{~min}($ Fig 6). The result showed that optimum temperature for activity of antimicrobial protease from Pseudomonas strain was $37^{\circ} \mathrm{C}$. Above this temperature the reaction might be occurring, as has also been shown by many workers (Mandl and Cohan, 1960) but the higher temperature could not be used at least in cases where screening of organisms for antimicrobial protease activity is carried out.

\section{References}

Anwar, A. and Saleemuddin, M., (1998). Alkaline proteases. A Review. Bioresource Technology 6(3): 175183.

Banerjee, U.C. Sani, R.K. Azmi, W. and Soni, R. (1999). Thermostable alkaline protease from Bacillus brevis and its characterization as a laundry detergent additive. Pro. Biochem. 35(1): 213219.

Cheetham, P.S.J. (1987). Screening for the novel biocatalsts. Enzyme. Microb. Technol 9:194-213.

Cooksey, K.E. (1971). Disc electrophoresis. In: Npru and Ribbons (eds.). Methods in microbiology. Academic Press, New York.5B:573.

Flaming, H.P., Etchells, J.L. and Costilow, R.H. (1975). Microbial inhibition by an isolate of Pediococcus from cucumber brines. Appl. Microbiol 30:1040-1042.

Gornall, A.G., Bardwill, C.J. and David, 
M.M.(1949). Protein estimation. J.Bio.Chem. 177-751.

Gupta, R., Beg, Q.K. and Lorenz, P. (2002). Bacterial alkaline proteases: molecular approaches and industrial applications. Appl. Microbiol. and Biotech. 59(1):15-32.

Lowry, O.H., Bouebrough, N.J., Farr, A.L. and Randall, R.L. (1951). Protein measurement with the folin reagent. J.Biol.Chem. 193-265.

Mandl, I. and Cohen, B.B. (1960). Bacterial elastase: isolation, purification and properties. Arch.Biochem.Biophys. 91:47-53.

Morihara, K. (1964). Production of elastase and proteinase by $P$. aeruginosa. J. Bacteriol. 88:745-757.

Morihara, K., and Tsuzuki, H. (1977). Production of protease and elastase by P.aeruginosa strains isolated from plants. Infect.Immun.15:679-685.

Morihara, K., Tsuzuki, H, Oka, T., Inowe, H. and Ebata, M.(1965). Pseudomonas aeruginosa elastase, isolation, crystallization and preliminary characterization. J.Biol.Chem. 240: 3295-3304.

Ramaley, R.F. (1979). Molecular biology of extracellular enzyme. Adv.Appl. Microbiol. 25:37-55.

Sachar, L.A., Winter, K.K., Sicher, N and Frankel, S. (1955). Photometric method for estimation of elastase activity. Proc.Soc. Exp.Biol.Med. 90:323-326.
Sandhia, G.S. and Prema, P. (1998). selection and optimal growth medium for the synthesis of alkaline proteinase from Bacillus SGP-26. J.Bacteriol. 57:629633.

Steele, D.B. and Stowers, M.D.(1991). Techniques for selection of industrially important microorganisms. Annu.Rev.Micobiol. 45:89-106.

Sticklend, H.L. (1951). The determination of small quantities of bacteria by means of Biuret reaction. J.Gen.Micobiol. 5:698-703.

Tsuchida, O. Yamagata Y., Ishizuka, T., Aria, T., Yamada, J., Takeuchi, M. and Ichishima, E. (1986). Selection of optimal growth medium for the synthesis of alkaline proteinase from Bacillus SGP-26. Curr. Microbiol. 14: 7-12.

Vancura, V. and Jandera, A. (1986). Formation of biologically active metabolite by rhizosphere microflora FEMS Symp. 33. In: Microbial Community in soil (Jensen, V., Kzotler, A and Sorenson, L.H. eds.). Applied Science Publisher. London and New York.

Wretland, B. and Wadstorm, T.(1977). Purification and properties of protease with elastase activity from $P$. aeruginosa. J.Gen.Microbiol. 103: 319-327.

\section{How to cite this article:}

Mohinder Kaur, Sheetal Rana and Kumari Manorma. 2020. Purification of Industrially Important Proteases from Pseudomonas Strain and Its Kinetic Studies. Int.J.Curr.Microbiol.App.Sci. 9(01): 900-909. doi: https://doi.org/10.20546/ijcmas.2020.901.100 